\title{
Impact of Tourism on Coastal Towns: From Improvisation to Planification
}

\author{
María José Piñeira Mantiñán ${ }^{*}$ and Xosé Manuel Santos Solla ${ }^{2}$ \\ ${ }^{1}$ Departament of History, Campus Universitario As Lagoas, s/n, University of Vigo, Spain \\ ${ }^{2}$ Department of Geography, Faculty of Geography and History, Pza, Universidade 1, University of Santiago de \\ Compostela, Spain
}

\begin{abstract}
Tourist activity in Spain during the 1960s boosted the development of tourist centres, especially along the Mediterranean seaboard, and at the same time resulted in the construction of a true building barrier along the seafront. Despite the existence of legislation which regulated land use planning and several planning tools, major landscape and environmental impacts occurred, due to the difficulty of managing a territory over which sustainable and systemic planning was almost inexistent. During the last decade, the concerns of land use planning agents about controlling the town growth on the Spanish seaboard has increased. They have responded by creating new regulations and promoting a participative planning that involves the land planning agents and the different administrations. This should allow a comprehensive approach.
\end{abstract}

Keywords: Land use planning on the seaboard, tourist activity, planning, land law, local administration.

\section{INTRODUCTION}

After the rapid growth of tourism in the 1950s in Spain, this sector has consolidated so much that today Spain is the second country in the world in terms of numbers of international tourists. In addition, tourism brings in economic contributions which are essential for the country's growth and development. In spite of the so called crisis of the sun and beach motivation -where the foundations of the Spanish tourism are set- said to be happening since the 80 s, no major impacts are evident. The prediction has, thus, turned out untrue and each year the records in relation to the number of tourists arriving in the country are superseded. At the same time, the process of change of the seaboard, especially the Mediterranean coast, has accelerated so that $40 \%$ of the first kilometre of the Mediterranean coast is estimated to be completely developed [1]. In addition to the international flows of visitors, we have to take into account domestic tourism, arising from the economic growth of Spain that has allowed its population to follow the Western social stereotype with tourist trips becoming a significant part of people's lives.

All the urban development on the coast is not attributable to tourism. Contemporary Spanish policy has clearly favoured Madrid, consolidating it as a capital of a modern and dynamic State. From this centre, development corridors have been designed around Seville, Valencia and Barcelona. Briefly, we could say that Spain has developed a solid central axis, which is Madrid, with other secondary inland poles, such as Zaragoza, and has also focused on the East and Southeast side generating a spectacular growth all along the Mediterranean coast, where tourism has just been one of many factors (Fig. 1).

*Address correspondence to this author at the Departament of History, Campus Universitario As Lagoas, s/n. University of Vigo; Spain;

Tel: +34667896202; Fax: +34981599935; E-mail: mariajose.pineira@usc.es
On the other hand, wide inland areas and many parts of the North and Northwest Atlantic coast have undergone a different dynamics which have, for instance, resulted in a demographic crises. Obviously, this outcome is neither spontaneous nor the product of misguided political management on behalf of the different autonomous regions. It comes as a result of the central Spanish State strategies.

An overview of tourism can be obtained by briefly analysing the recent details of the international arrivals. In year 2006, Spain welcomed 58.5 million tourists from abroad, mainly from the United Kingdom (16.1), Germany (10.1), and France (9.1). Only a decade before, in 1996, the total amount was 41.3 millions. WTO estimates that Spain will receive 71 million international tourists by 2020 . Along with these figures, we have to take into account additional hotel space for 1.5 millions tourists and also important proposals affecting applications for second residences. It is important to acknowledge that $62 \%$ of the trips undertaken by Spaniards do not imply accommodation expenses as they use their own residences or stay with friends [2].

Another significant characteristic is the spatial concentration of tourism, $90 \%$ of international flow is concentrated in only 6 autonomous regions: Catalonia (15.0), Balearic Islands (10.1), Canary Islands (9.6), Andalusia (8.5), Valencia (5.4), and Madrid (3.9). That reveals the clear tendency towards the Mediterranean coast, apart from the Canary Islands and Madrid, the last acting as a gateway for many travellers.

Economic variables indicate that the tourist sector employs 2.5 million people in Spain, which represents approximately $12 \%$ of the employment, although there are big differences among autonomous regions. There is a similar pattern with tourists' disbursement, which meant a volume close to $€ 50,000$ millions in 2006 from international tourism. It is assumed that tourism represents in Spain more than $11 \%$ of GDP, again with patent differences regarding 


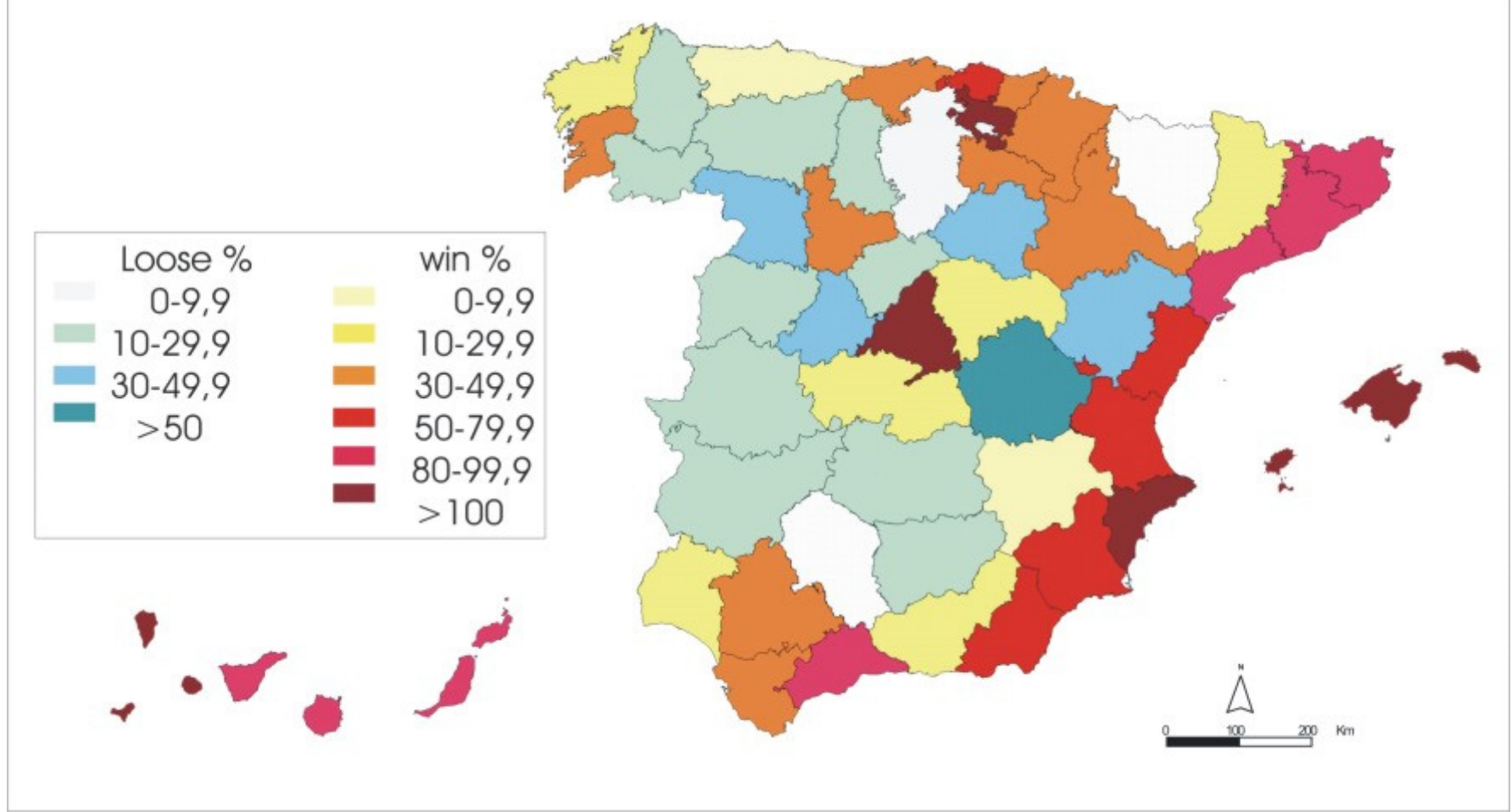

Fig. (1). Demographic growth of the Spanish provinces 1960-2005. Source: Compiled from of the National Institute of Statistics (INE).

regions, and very high percentages being typical of the Balearic and Canary Islands [3].

The fact that tourism is a spatial phenomenon has often gone unnoticed due to the repercussions it has had on the economy of some communities. On the one hand, its degree of development determines the direction of town planning since this activity is related to the creation or expansion of the activity, which determines the land market, construction, real estate development and services, and on the other hand, it prompts the development of the infrastructures as good accessibility (highways, airports, ports) becomes imperative.

\section{EVOLUTION OF THE TOURIST ACTIVITY IN SPAIN}

Tourism in its present form is a recent phenomenon which was initiated at the same time as industrial revolution. Nevertheless, there is evidence in the course of history which can be related to this phenomenon. For instance, during the Spanish Roman period, the spa tourism was associated with the sea and the beach. The housing estate of Empuries (Costa Brava) was already a destination at that time. During the middle ages, religious tourism launched Santiago de Compostela as a main destination, being a focus for pilgrims from all over Europe and bringing about the creation of inns and communication routes. But it is not until the 19th Century when many European aristocrats and members of the royal family started to come to the mild beaches of Northern Spain, such as San Sebastian or Santander, to sunbath, while the hotter Southern areas were promoted as winter destinations.

After World War II, tourists flows towards Spain became heavier, especially to the South, where the climate met many Europeans' longing for sun and beach [4]. This change in the destination based on the new taste for heat and beach was not spontaneous but was prompted by a series of circumstances. On the one hand, there was a dictatorial regime eager to open up towards Europe and be accepted by Western democracies, and willing to offer all conveniences so that the dry areas of the Mediterranean coast could be transformed into building areas, allowing the strengthening of business and creation of new infrastructures. On the other hand, the European powerful tour operators established control over the flow and destination of millions of tourists in the economic growth post World War 2. This was a perfect combination for success.

As the 1963 World Bank report confirms [5], the fifties brought a tourist boom despite the skepticism of the international authorities. The impact on the economy of the country was big enough to be included in the economic planning process. At that time, Spain followed Italy in terms of numbers of tourists, but there was no clear pattern. The later focuses on sun and beach tourism involved uncontrolled growth of that activity and the urgency of involving town planning. This situation called for a tourist plan, which fixed a set of regulatory measures, but such a plan did not emerge until 1960 when the first tourist plan was created (19641967). Its context was the promotion of the Economic Stabilisation Plan, the objective of which was to put an end to regional discrepancies and improve economic conditions in the less developed communities. But this plan was never completed. Attention focused on the need to promote Spain both abroad and at home in order to avoid concentration of the tourism on particular parts of the Mediterranean coastline. By that time eleven provinces had $82 \%$ of the accommodation available in the country, with the Balearic Islands (35.9\%), Gerona-Alicante (32\%), and then Canary 
Islands (8.1\%), and the Malaga-Cadiz area (6.2\%) in leading positions. Promotional efforts extended throughout 19681971, thanks to the second plan, though its target was to redistribute tourist flows in order to avoid overdevelopment of the most popular destinations.

From the time of the third plan (1972-1975), new factors related to town planning, such as accommodation capacity, spa centre modernisation, reservoir surrounding planning, hunting/fishing preserves, and rural improvements were introduced. These new concepts were created in order to plan and develop tourist spaces. Among them, we can highlight the concept of National Tourist Attractions (Table 1) and that of National Tourist Areas (Table 2), where plans for the promotion of the area and town planning and plans for promotion of the area and zonal and town planning, respectively, were implemented [6].

Table 1. National Tourism Attractions

\begin{tabular}{|c|c|}
\hline Municipalities & Province \\
\hline Orihuela (Lo Mate) & \multirow{2}{*}{ Alicante } \\
\hline Santa Pola & \\
\hline Almería & \multirow{3}{*}{ Almería } \\
\hline El Ejido & \\
\hline Roquetas de Mar & \\
\hline Alcalá de Chivert & Castellón \\
\hline Algeciras & \multirow{6}{*}{ Cádiz } \\
\hline Chiclana de la Frontera & \\
\hline La Línea de la Concepción & \\
\hline Los Barrios & \\
\hline San Roque & \\
\hline Tarifa & \\
\hline Tossa de Mar & Gerona \\
\hline Motril & Granada \\
\hline Ayamonte & \multirow{4}{*}{ Huelva } \\
\hline Cartaya & \\
\hline Palos de la Frontera & \\
\hline Punta Umbria & \\
\hline Arta & \multirow{2}{*}{ Islas Baleares } \\
\hline Es Mercadal & \\
\hline Benahavis & \multirow{2}{*}{ Málaga } \\
\hline Marbella & \\
\hline Cartagena & \multirow{3}{*}{ Murcia } \\
\hline Mazarron & \\
\hline San Javier & \\
\hline O Grove & Pontevedra \\
\hline San Miguel & \multirow{2}{*}{ Santa Cruz de Tenerife } \\
\hline Santa Cruz de Tenerife & \\
\hline Tortosa (La Bassa dels Ganduls) & Tarragona \\
\hline
\end{tabular}

Source: [6].
Table 2. Municipalities Declared as Priority Tourist Areas in 1977

\begin{tabular}{|c|c|}
\hline Municipalities & Province \\
\hline Roquetas de Mar & Almería \\
\hline Tossa de Mar & Gerona \\
\hline Arta & \multirow{2}{*}{ Islas Baleares } \\
\hline Es Mercadal & \\
\hline Marbella & Málaga \\
\hline Santa Cruz de Tenerife & Santa Cruz \\
\hline Alicante/Alacant (Isla Plana o Un) & \multirow{3}{*}{ Alicante } \\
\hline Benidorm & \\
\hline El Campello & \\
\hline Arenys de Mar & \multirow{8}{*}{ Barcelona } \\
\hline Calella & \\
\hline Canet de Mar & \\
\hline Castelldefels & \\
\hline Malgrat de Mar & \\
\hline Pineda de Mar & \\
\hline Santa Pol de Mar & \\
\hline Santa Susanna & \\
\hline Laredo & \multirow{2}{*}{ Cantabria } \\
\hline Santander & \\
\hline Benicasim/Benicassim & Castellón \\
\hline Alp & \multirow{10}{*}{ Gerona } \\
\hline Blanes & \\
\hline Calonge & \\
\hline Castell-Platja d'Aro & \\
\hline Lloret de Mar & \\
\hline Palafrugell & \\
\hline Palamos & \\
\hline Roses & \\
\hline Sant Feliu de Guixols & \\
\hline Torroella de Montgri & \\
\hline Monachil & Granada \\
\hline Donostia-San Sebastian (Zubieta) & Guipuzcoa \\
\hline Almonte & Huelva \\
\hline Aisa & \multirow{2}{*}{ Huesca } \\
\hline Sallent de Gallego & \\
\hline Alcudia & \multirow{5}{*}{ Islas Baleares } \\
\hline Andraitx & \\
\hline Calvia & \\
\hline Capdepera & \\
\hline Ciutadella de Menorca & \\
\hline
\end{tabular}


(Table 2) contd.....)

\begin{tabular}{|c|c|}
\hline Municipalities & Province \\
\hline Felanitx & \multirow{18}{*}{ Islas Baleares } \\
\hline Formentera & \\
\hline Llucmajor & \\
\hline Manacor & \\
\hline Muro & \\
\hline Palma de Mallorca & \\
\hline Pollenca & \\
\hline San Jose & \\
\hline Sant Antoni de Portmany & \\
\hline Sant Joan & \\
\hline Sant Llorenc des Cardassar & \\
\hline Sant Lluis & \\
\hline Santa Eugenia & \\
\hline Santa Margarita & \\
\hline Santanyi & \\
\hline Ses Salines & \\
\hline Soller & \\
\hline Son Servera & \\
\hline Las Palmas de Gran Canaria & \multirow{2}{*}{ Las Palmas } \\
\hline San Bartolome de Tirajana & \\
\hline Benalmadena & \multirow{5}{*}{ Málaga } \\
\hline Estepona & \\
\hline Fuengirola & \\
\hline Mijas & \\
\hline Torremolinos & \\
\hline Adeje & \multirow{2}{*}{$\begin{array}{l}\text { Santa Cruz } \\
\text { De Tenerife }\end{array}$} \\
\hline Puerto de la Cruz & \\
\hline Cambrils & \multirow{2}{*}{ Tarragona } \\
\hline Vila-seca i Salou & \\
\hline Gandia & Valencia \\
\hline
\end{tabular}

But despite these legal measures and the land law passed in 1956, a disproportionate amount of building growth was taking place at the main tourist destinations -especially around the Mediterranean coastal strip- and this did not slow down. Why then did this planning chaos exist? The answer lies in the failure, in most of cases deliberate, to comprehend concepts like development potential, compulsory handover of land free of cost, public or private sector initiative planning, and urban building standards. Even when City Councils designed their Urban Development Plans, many involved agents, both public and private, allied with a focus on speculation, the negative impact on numerous town centres and long coastal strips was considerable [7] (Fig. 2).

As a result, spontaneous population centres developed with neither planning nor clear objectives. They simply followed the pace dictated by the market, based on an amalgam of individual initiatives lacking any consideration for infrastructure or facilities. Moreover, this sort of development caused conflicts between population and the administration, as it led to struggles over land use and a requirement for a larger infrastructure for sanitation and water supply. There was a need for investment-which, because the infrastructure had to meet the demands of the peak months of the tourism season remained unused or under-used for the rest of the year. One example was the city of Torrevieja, which underwent a growth of tourism later than other towns in the Alicante area, such as Benidorm, because other activities like salt works exploitation or fishing were still important for its economy and there was a lack of business initiative. When the city finally started to encourage tourism, the option chosen was based on the development of second residences promoted by the estate agencies. This kind of tourism implies the use of virtually all the municipal land, so a priori the landscape in Torrevieja is less shocking than that of Benidorm, which was overbuilt at the seafront with high structures that created a different type of landscape. In reality, however, land use and its associated problems were even more acute in Torrevieja. The impact on land use impact on Benidorm coastline was terrible too but in a different way. As the demand for tourist space developed it was rapid based on creating hotel availability and had a strong business initiatives, its driving force. Even though the 1956 planning policies established urban development, the fact that land was often owned by hoteliers and that the building land was scarce and the demand high, caused the development to be based on high buildings at the seafront. Today a building blockage can be found at the sea-frontage and the city has a strong feeling of congestion and overcrowding. The only built-up areas with open spaces are located at the expansions adjacent to the old town and near the foothills of Sierra Helada. Nevertheless, the city's compact urban-tourist pattern made resource management easier and allowed this municipality to retain a big part of its space for future development [9].

This situation is similar in the rest of the Mediterranean coastal strip, where municipalities regarded tourism as a key to the economic boom and as a substitute for the traditional activities -normally extensive agriculture- since it undoubtedly resulted in an inflow of capital investment (even if it was foreign), employment creation, and a better standard of living for indigenous population. Questions on the quality of urban development remained and for many it was dubious. What mattered was the short term growth and quick profits while planning was pushed into the background or even ignored. In the circumstances, the 1970s brought a new attempt to control the Mediterranean's most oversubscribed areas by declaring some municipalities as priority tourist areas, where the construction of new buildings and improvement or enlargement of existing ones required a planning permission from the Ministry of Information and Tourism. However, the results were not as expected. In some cases, as in Andalusia, the administration tried to create regulations on tourism in the Sun Coast taking into account matters like urban planning and infrastructure and even banned division into plots of areas set aside for speculative housing. But in the end, it was no more than an informative tool that was never implemented [10]. 


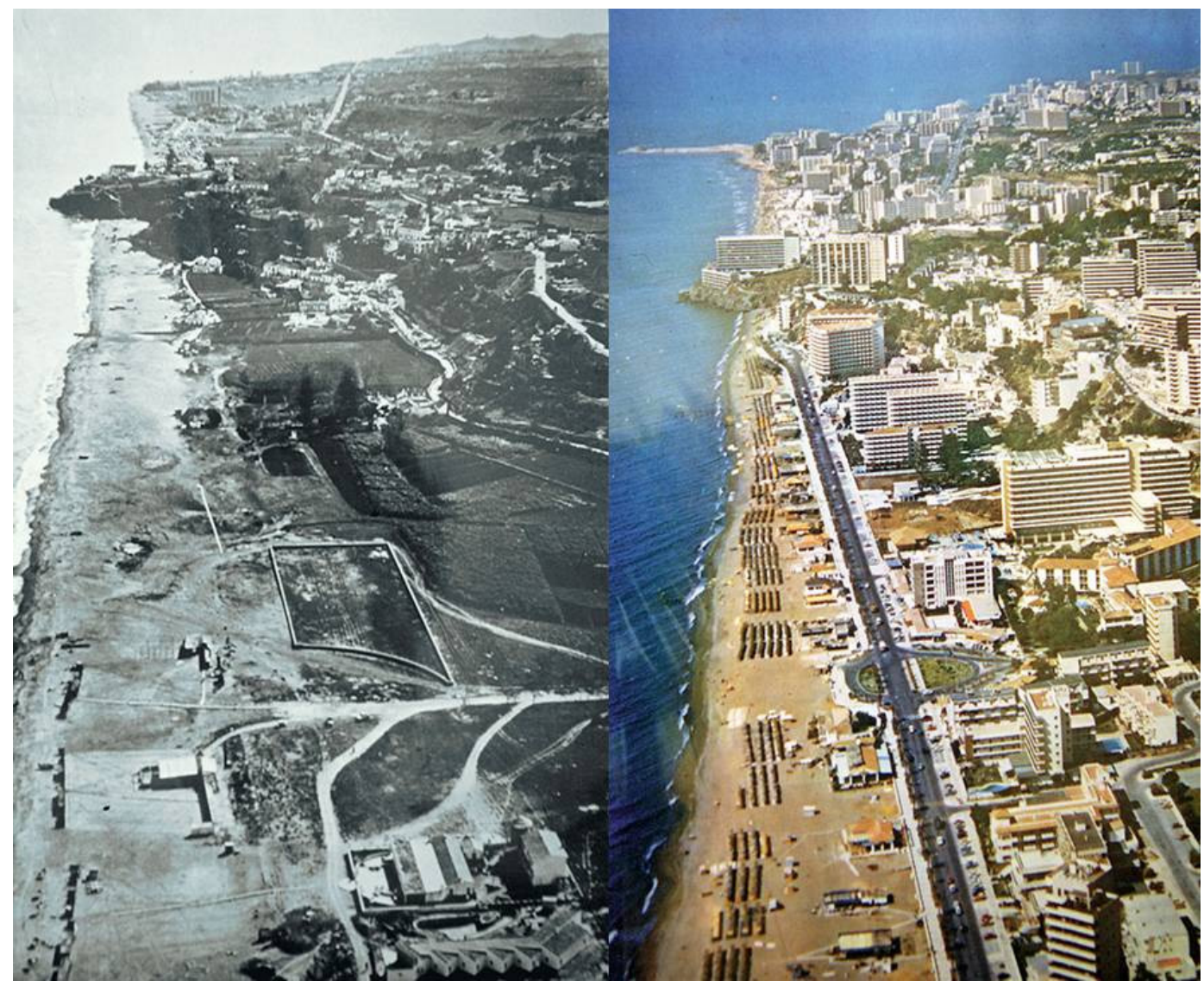

Fig. (2). Process of urbanisation of Torremolinos. Comparative of the coastal landscape of 60's and the present one. Source: [8].

In the 1980s, as the new Spanish territorial approach moved towards the declaration of autonomous regions, the central government transferred some authority and power, for issues such as those concerning town planning, tourism, and transport, to these autonomous regions. In principle, this seemed a good step as it would enable these regions to create their Integrated Development Plans according to the European model, but in reality things proved to be very different.

\section{FROM IMPROVISATION TO THE PLANNING OF A TOURIST STRATEGY}

As we mentioned at the beginning of this article, tourism (along with building) is one of the key sectors of the Spanish economy. The outcome so far has been a very questionable tourist pattern. The creation of infrastructure and facilities related to airports, highways, sewage treatment plants has been associated with this pattern. Nevertheless, tourism has been too often the perfect excuse for justifying a low sustainable growth. Marinas and golf courses are two examples of activities linked to the aggressive construction of residential complexes, hotels, and shopping centres. If complexes of this kind were built in all 232 ports $(107,772$ moorings) spread along $7,880 \mathrm{~km}$ of Spanish seaboard, the impact would be enormous [11]. As far as golf courses are concerned, they are most significant in their negative impact when built in areas where droughts are a major issue: the 300 Spanish golf courses are said to have a water consumption equivalent to that needed for 4.5 million people. Although it is true that a high proportion of that water is recycled, it is often forgotten that there are many residential complexes associated to those courses that need also to be provided with a water supply.

With regard to building structures, the trend identified in the 1960s and 1970s is still going on when uncontrolled development led Spain to build more dwelling places in 2005 than France, Germany, and Italy put together [12]. At the present time Spain has over 500 dwelling places per 1000 inhabitants, the highest in Europe. It is on the coastline that the impact is greatest. A study carried out by Greenpeace [13] shows that 2200 new hectares on the coast have been declared developable last year (2006) and in addition, data published by the Sustainability Watch show that from 1987 to 2000 the developed land increased by an average of $30 \%$ up to a total of $2000 \mathrm{~km} 2$. The regions with the highest percentages were Murcia (63\%), Valencia $(50 \%)$, and the Balearic Islands (41\%). Future prospects do not get any better, as 2000 ha of land formerly used for agriculture are estimated to have already been declared as urban zones. Only Shanghai (China) and Osaka (Japan) record a greater development growth than Malaga. This has happened despite the law from 1989 which regulates the $7880 \mathrm{~km}$ of coast in Spain -now considered as public land owned by the State subject to a specific legal framework- which entitles the Administration to take action in favour of its protection and preservation due to its high rich heritage value and its vulnerability to the growing demand of land. This state of affairs is confirmed by the fact that the $5 \mathrm{~km}$ of coast in Malaga (7\% of its territory) are inhabited by $35 \%$ of the whole population, and at a density far surpassing the Spanish 
average, and trebling seasonally in the main tourism areas, which is $82 \%$ concentrated on the coast. The Coast Law establishes an inland easement area of $100 \mathrm{~m}$. depth, which can be larger at the discretion of the autonomous region. In Galicia, for example, the easement zone has been set at 200 $\mathrm{m}[14]$.

Tourism is a major consumer of space in coastal areas with a high environmental value and can cause critical impacts if load capacity is not taken into account. The indiscriminate occupation of coastal areas is irreconcilable with the sustainable development promoted by the administration. The carrying capacity of some areas is never considered and this produces a severe impact on resources. In short, the problem lies in the fact that, typically, urban development plans, which should meet economic, environmental and social sustainability criteria in order to improve the quality of life, do not respect current town planning and environmental regulations [15].

Despite the situation that had emerged by the beginning of the 1990s, there was a clear need for a major strategic change of direction. Better management and closer coordination; the interrelated components of tourism will eventually achieve a more optimal level of social, economic, and environmental organisation of the tourist areas and enhance their competitiveness. The old pattern of standardized and rigid products will be replaced by greater diversification and products more sensitive to the needs of tourist. Individuals do not wish to be treated as part of a shapeless mass anymore and also seek an active role in their tourist experiences. This new orientation began at the end of the 1980s, when the image of Spanish destinations was badly damaged and there was a fear of lower competitive ability. The perceived solution was that of reformulating tourist strategies and improving coordinated procedural guidelines, in which all involved agents and sectors could participate.

The new tourists were focused on developing sustainable and higher quality tourism, even in those established destinations where the previous strategies had been based on the sun and beach pattern. The local administration played an essential role in achieving this new order, since it was the only agent that could coordinate key elements such as heritage management, infrastructures, services (garbage, urban transport), town planning, and environmental protection by drawing up specific plans. In Valencia, a more restrictive law was found to be necessary in order to enforce the town planning regulations when faced with misuse of space and lack of transparency. Similarly, the Sun Coast created the Plan Cualifica [16], which intends to improve the quality and competitiveness of tourism by following strategies based on qualitative rehabilitation of heritage and tourist space. Their aim of differentiation as opposed to standardisation has led them to analyse the evolution of their main tourist indicators, the big changes in motivations, the facility evolution, the population evolution, competition factors, sustainability, etc. [17]. An inclusive analysis was then set out in order to allow all the employers' organisations and tourist sector institutions to express their opinion on the future pattern to be followed and the necessary strategies and actions to be taken. Another example is that of the North part of the coast of the province of Alicante. This is a joint enterprise at a supra-municipal level by which Benidorm and nearby town councils have signed agreements to promote resources in the inland municipalities which have been included as components of the Benidorm tourist destination (Jalón, Benissa, Gaudalest, Callosa d'En Sarriá) [7]. The aim is here is to develop a polar tourism, which offers a diverse and complementary product. This trial, along with the Aquitania model, requires a big effort as it needs a very important level of town zoning and planning. This is a process which has yet to be fully implemented and understood. Another factor to take into account is the land zoning and use optimisation. Improvised town planning in the 1960s and 1970s did not have the suitable instruments of control and, therefore many residential complexes -even those having internal planning- developed in an irregular way, disregarding a wider overview of spatial planning. It was a spatially aggressive pattern due to its rapid and non regulated growth, which sought short-term that favouring individual interests and market forces. New trends are leading to a tourist space pattern based on a slower development and emerging from a deeper analysis of the existing resources, the market, and the establishment of longterm strategies. It must follow those planning and building regulations which protect the general interest, it must be comprehensive and its objective must be sustainable development. The administrative coordination must be horizontal to solve problems globally, it should collaborate with the private sector in order to combine efforts, optimise investments to respond to demand, develop better quality, and achieve overall targets agreed within the three levels of administration and business.

The 1992 Master Plan on Spanish Tourism Competitiveness (called FUTURES) was based upon these principles. Its main goals were to improve tourist services and products by promoting quality, restoring the value of cultural and natural heritage, diversifying the product in order to make tourism less seasonally-dependant, strengthening the business network, upgrading the human resources, promoting research and development, and incorporating new technologies through the coordination of both the public and private sector. It also outlined new plans aimed at the recovery and restoration of mature destinations. The first of such plans was launched in Calviá, Menorca. They were so successful that the Secretary of Commerce and Tourism decided to create new plans along that same line aimed for emerging destinations: the Dynamisation Plans [18].

With both bodies cooperation model was established, which achieved important growth in the late 1990s both in the number of tourists and in terms of income. Tourism was one of the main economic sectors contributing $10.6 \%$ of the GDP in the year 1998 [19]. But progress had to be maintained and the PICTE-2000 (Integral Plan for the Quality of Spanish Tourism) was established with this purpose in mind. Again, it was based on the idea of achieving comprehensive quality, and the introduction of key statistical information and economic analysis. This is a programme aims to diffuse a brand image that places it apart from others and allows Spanish tourism to become international leader. 


\section{CONCLUSIONS}

In recent years, an effort has been made by public administrations and also by the private sector to diversify and improve Spanish tourism. However, prevailing trends are difficult to modify. One of the most evident is the great potential of residential tourism, which seems to be expanding by joining two of the most important economic activities in Spain. However, a study on the Mediterranean region and the Canary Islands carried out by Exceltur [1], a group that involves many of the major companies of this sector, has revealed the weaknesses of the residential pattern both in the creation of employment and in the generation of expenditure and the economic dynamism. But an aspect of this analysis we would like to highlight is that the average occupation of residential accommodation was, in terms of number of days/people, much lower that in regulated establishments: 48 nights against 144 . The question that arises is whether such an intense consumption of scarce territory is sustainable for such a limited and seasonal use.

Administrations must insist on the need for promoting a pattern in which tourism, territorial organisation, the optimisation of the existing resources, and the implementation of new patterns for the environment, the landscape, and culture do not have to be mutually exclusive.

However, there is still a conflict among the physicalenvironmental and social-institutional systems on the one hand with the market, which determines that the number of coastal areas in which the process of development in recent years remains high. The essential co-ordination and interaction is not occurring. It is true that the tourism products have been diversified and that they now include a significant cultural dimension with some rural tourism, but local agents have continued to consume land both on the sea and inland by means of the large increase of marinas or the construction of additional facilities (golf courses, water parks, etc.) to cover the needs of the new customers. But it is in the field of building where the new strategies are best reflected. Horizontal building tends to replace vertical building. Once a large amount of the coastal area had been occupied with large housing developments but the new vision offers a more varied perspective with detached houses or smaller buildings, always surrounded by green areas and a variety of facilities. The beachfront is now less important than the services provided and the landscaping. All in all, new perspectives are leading to familiar results: a disproportionate consumption of land that spreads toward municipality's further inland.

We might reflect more fully on the Spanish development model. Módenes and López-Colás [20] have shown the existing relationship between the dominant development and the way in which we build leisure residential areas. They point out that the high densities in our cities are a compensating influence on the extensive processes of second residence.
Bearing in mind this situation, the future depends on a local or regional tourism plan that progresses the situation at exists at the present time to the reality we want. This requires an integral management that allows more flexibility and guarantees the coordination of, and agreement between the public and private sector. This is the only way to incorporate the objectives in the general development policies, to coordinate all the elements within the sector, to guarantee the resource preservation, to minimise problems, and to optimise profits.

\section{REFERENCES}

[1] Exceltur. Impactos sobre el entorno, la economía y el empleo de los distintos modelos de desarrollo turístico del litoral mediterráneo español, Baleares y Canarias. Madrid: Deloitte-Exceltur 2005. Available from: http://www.exceltur.org.

[2] Lopez OD, Pulido J (Dir.). La actividad turística española en 2005 , Madrid: Aecit-Editorial Universitaria Ramón Areces 2006.

[3] Rodriguez DMM, Guisado TM. Competitividad y análisis estratégico del sector turístico en Galicia: consideraciones para la mejora competitiva. Santiago de Compostela 2003; 12(1): 145-66.

[4] Urry J. The Tourist Gaze. Londres: SAGE 2002.

[5] Barrado D, Galiana L. Ideas y modelos de planificación territorial en los orígenes del turismo de masas español. Revista de Estudios Turísticos 2006; 167: 7-36.

[6] Galiana L, Barrado D. Los Centros de Interés Turístico Nacional y el despegue del turismo de masas en España. Investigaciones Geográficas 2006; 39: 73-93.

[7] Baños CCJ. Modelos turísticos locales. Análisis comparado de dos destinos de la Costa Blanca. Investigaciones Geográficas 1999; 21: 3557.

[8] Turismo y especulación en la Málaga del desarrollismo. Avaliable from: http://www.eldirariosur.es

[9] Vera Rebollo JF, Lopez PF, Marchena GMJ, Anton CS. Análisis Territorial del Turismo. Barcelona: Ariel 1997.

[10] Galacho JFB. Urbanismo y turismo en la Costa del Sol. Málaga: Universidad de Málaga 1996.

[11] Fira De B. El sector de la náutica deportiva y de recreo en España 2006 Avance del informe económico. Barcelona: Departamento de Investigación y Estrategia de Mercados 2006.

[12] Gandarias M. En defensa del turismo residencial. 2007; Available from: http://www. cincodias.com/artic ulo/opinion [Cinco Días, Madrid, 17 Agosto 2007].

[13] Greenpeace. Destrucción a toda costa. 2006; Informe sobre la situación del litoral español. Madrid: Greenpeace 2006. Available from: http://www.greenpeace.org/raw/content/espana/reports/destrucci-n-a-todacosta-2006.pdf

[14] Lei 6/2007 del 11 de mayo, de medias urgentes en materia de ordenación do territorio e do litoral de Galicia Available from: http://www.xunta.es/Dog/Dog2007.nsf/FichaContenido/153B6?OpenD ocument [Diario Oficial de Galicia, 11 Mayo 2007].

[15] De La Sostenibilidad. Informe de Sostenibilidad en España Alcalá de Henares 2006. Available from: http://www. sosteni bilidad-es.org

[16] Available from: http://www.qualifica.org

[17] Yepes PV. Estrategia y política turística de la Comunidad Valenciana: su incidencia en el litoral. Cuadernos de Turismo. Murcia: Universidad de Murcia 2002; 009: 165-73.

[18] Ministerio De Industria Y Turismo. Plan marco de competitividad. Plan Futures 1992-1995. Available from: http://www.sgt.tourspain.es

[19] San Pedro MMA. AER. El Plan de Dinamización Turística del Alto Asón. Cuadernos del Valle del Asón. Cantabria: AER 2002; 7: 3-8.

[20] Modenes J, Lopez-Colas J. Second homes and compact cities in Spain: two elements of the same system. Tijdschrift voor Economische en Sociale Geografie 2007; 98(3): 325-35. 